\title{
HUBUNGAN KUALITAS PELAYANAN TERHADAP KEPUASAN PASIEN BPJS KESEHATAN DI PUSKESMAS II DENPASAR SELATAN
}

\section{Relationship Service Quality Into Patient' Satisfaction Of The National Healthcare Security In Public Health Centre Ii South Denpasar}

\author{
IGAA Sherlyna Prihandhan, ${ }^{1}$ Nina Rismawati Hakim, ${ }^{2}$ I Gede Wirajaya, ${ }^{3}$ \\ ${ }^{1}$ Dosen Departemen Manajemen Keperawatan, STIKES Bina Usada Bali \\ ${ }^{2}$ Dosen S1 Keperawatan, STIKES Bina Usada Bali \\ ${ }^{3}$ Dosen S1 Keperawatan, STIKES Bina Usada Bali \\ Korespondensi: sherlynaprihandhani@gmail.com
}

\begin{abstract}
ABSTRAK
Salah satu penyebab buruknya aspek kesehatan di Indonesia adalah tidak meratanya pelayanan kesehatan yang berkualitas bagi seluruh rakyat Indonesia. Mengatasi permasalahan tersebut, pemerintah mengeluarkan Undang-undang No.40 tentang Sistem Jaminan Sosial Nasional (SJSN). Berdasarkan data di Puskesmas II Denpasar Selatan terdapat 689 orang pengguna BPJS, dimana setelah diwawancarai sebanyak sepuluh orang terdapat tujuh di antaranya mengatakan tidak puas. Penelitian ini bertujuan untuk mengetahui hubungan kualitas pelayanan terhadap kepuasan pasien BPJS Kesehatan di Puskemas II Denpasar Selatan. Jenis penelitian yang digunakan yaitu deskriptif analitik dengan pendekatan cross sectional. Sampel penelitian yang digunakan adalah pasien yang berkunjung atau berobat ke Puskesmas II Denpasar Selatan menggunakan BPJS sebanyak 253 orang. Hasil penelitian ini menunjukkan bahwa terdapat pengaruh yang signifikan antara kualitas pelayanan $\mathrm{p}$ value $=0,001$ dengan kepuasan pasien dimana nilai $\mathrm{p}<0,05$. Penelitian ini diharapkan dapat dijadikan referensi dan acuan untuk penelitian selanjutnya agar dapat melakukan pengkajian lebih mendalam tentang faktor-faktor lainnya yang berkontribusi terhadap kepuasan pasien pengguna BPJS seperti suasana dan image.
\end{abstract}

Kata Kunci $\quad$ : BPJS, Kepuasan, Pasien

\begin{abstract}
One of the causes of poor health in Indonesia is the uneven quality of health services for all Indonesians. Addressing the issue, the government passed Law No.40 on the National Social Security (NSS) System. Based on data in Public Health Centre II South Denpasar there are 689 users of BPJS, after being interviewed of ten people, there are seven out of ten people said not satisfied. This study aimed at determining relationship facilities, service quality and communication into patient'satisfaction of the national healthcare security in Public Health Centre II South Denpasar. The type of research used was analytical descriptive with cross sectional approach. The sample of the research used was the patients who visited as Public Health Centre II South Denpasar about 253 people. The results of this study indicated that there was a significant influence between $p$ value of service quality $=0,001$ with patient satisfaction, $p$ value $<0,05$. This study is expected to be a reference and guidance for further research in order to conduct more in-depth assessment of other factors which contribute to patient's satisfaction of BPJS users such as atmosphere and image.
\end{abstract}

Keywords : BPJS, satisfaction, patient 
IGAA Sherlyna Prihandhani: Hubungan Kualitas Pelayanan Terhadap Kepuasan Pasien BPJS

Kesehatan di Puskemas II Denpasar Selatan

\section{Pendahuluan}

Salah satu penyebab buruknya aspek kesehatan di Indonesia adalah tidak meratanya pelayanan kesehatan yang berkualitas bagi seluruh rakyat Indonesia. Mengatasi permasalahan tersebut, pemerintah pada tahun 2004 mengeluarkan Undang-undang no. 40 tentang Sistem Jaminan Sosial Nasional (SJSN). Salah satu program dari SJSN adalah Jaminan Kesehatan Nasional (JKN) melalui suatu Badan Penyelenggara Jaminan Sosial (BPJS) (Herliani, 2015).

Badan Penyelenggara Jaminan Sosial atau BPJS kesehatan adalah badan hukum publik yang berfungsi menyelenggarakan program jaminan kesehatan bagi seluruh masyarakat Indonesia termasuk warga asing yang bekerja paling singkat enam bulan di Indonesia (UU BPJS, 2011).

Hasil perolehan data dari pihak BPJS Kesehatan Divisi Regional XI tahun 2015 menunjukkan bahwa hasil survei kepuasan peserta BPJS di Indonesia adalah 78,9\%. Di Bali terdapat 2.178.448 orang yang menggunakan BPJS dan sebesar 78,10\% pengguna BPJS sekitar 1.701 .368 orang mengatakan puas.

Dari data yang didapat dalam jurnal tahun 2014 berjudul "Indeks Kepuasan Peserta dan Faskes terhadap BPJS Kesehatan Sukses Lampaui Target" dari total 17.280 responden masyarakat, sebanyak $81 \%$ menyatakan puas terhadap BPJS Kesehatan. Angka tersebut melampaui target kepuasan masyarakat yang ditetapkan oleh pemerintah, yaitu sebesar $75 \%$. Persentase total sebesar $81 \%$ itu merupakan gabungan dari indeks kepuasan peserta terhadap layanan di Fasilitas Kesehatan Tingkat Pertama (FKTP), Fasilitas Kesehatan Rujukan Tingkat Lanjut (FKRTL), Kantor Cabang, dan BPJS Kesehatan Center.". Persentase indeks kepuasan peserta terhadap fasilitas kesehatan diperoleh dari gabungan antara kepuasan peserta di FKTP 80\% dan di FKRTL $82 \%$. Pada tingkat FKTP, indeks kepuasan peserta yang dilayani oleh Puskesmas terbilang sama persis dengan indeks kepuasan peserta yang dilayani Dokter
Praktek Perorangan (DPP) dan Klinik, yaitu sebesar $80 \%$.

Puskesmas II Denpasar Selatan terdapat 689 orang pengguna BPJS untuk bulan Juli tahun 2016 dimana setelah diwawancarai pada tanggal 16 Juli 2016 sebanyak sepuluh orang, terdapat tiga diantara sepuluh orang mengatakan puas dan tujuh orang sisanya tidak puas disebabkan oleh faktor pelayanan.

Berdasarkan uraian di atas, maka peneliti tertarik untuk melakukan penelitian mengenai "Hubungan Kualitas Pelayanan terhadap Kepuasan Pasien BPJS Kesehatan di Puskesmas II Denpasar Selatan”.

\section{Metode}

Penelitian ini menggunakan desain penelitian korelasional dan dengan rancangan penelitian cross sectional yaitu merupakan jenis penelitian yang menekankan waktu pengukuran observasional data variabel independen dan dependen hanya satu kali pada satu saat. Pada jenis ini, variabel independen dan dependen dinilai secara simultan pada suatu saat. Tentunya tidak semua subjek penelitian harus diobservasi pada hari atau waktu yang sama, akan tetapi baik variabel independen maupun variabel dependen dinilai hanya satu kali saja (Nursalam, 2013).

Populasi dalam penelitian ini adalah seluruh peserta BPJS di Puskesmas II Denpasar Selatan yang berjumlah 689 orang. Pengambilan sampel dilakukan dengan teknik purposive sampling. Purposive sampling merupakan metode pencuplikan non random yang ditentukan berdasarkan pertimbangan untuk mencapai tujuan tertentu (Sugiyono, 2010). Sampel penelitian ini adalah 253 responden yang ditentukan berdasarkan rumus sampel.

Instrumen penelitian dilakukan untuk memperoleh informasi dari responden, dan peneliti menggunakan alat pengumpulan data berupa kuesioner. Kuesioner tersebut terdiri dari kuesioner kualitas pelayanan yang terdiri dari tujuh pernyataan, menggunakan skala guttman dengan kategori "Ya atau Tidak". Diberikan skor "1" apabila jawaban "Ya" dan skor "0" apabila jawaban "Tidak". Kuesioner 
IGAA Sherlyna Prihandhani: Hubungan Kualitas Pelayanan Terhadap Kepuasan Pasien BPJS

Kesehatan di Puskemas II Denpasar Selatan

kepuasan pasien BPJS terdiri dari delapan item pertanyaan menggunakan skala Likert dengan kategori skor: $5=$ sangat puas $4=$ puas, $3=$ cukup puas, $2=$ tidak puas, $1=$ Sangat tidak puas.

Pengumpulan data dilakukan pada bulan Agustus 2017. Pengambilan data kepada peserta BPJS di Puskesmas II Denpasar Selatan dilakukan saat pasien melakukan pengobatan ke puskesmas setiap harinya hingga memenuhi jumlah sampel yang diinginkan oleh peneliti.

Analisis data yang digunakan dalam penelitian ini adalah uji korelasi Chi Square untuk mengetahui hubungan kedua variabel dengan skala ordinal.

\section{Hasil}

Data yang didapatkan dianalisa dengan analisa univariat dan bivariat sebagai berikut:

\section{Jenis Pekerjaan}

Tabel 1.Gambaran Distribusi Frekuensi

Responden Berdasarkan Jenis Pekerjaan

\begin{tabular}{|c|c|c|}
\hline Kategori & $\mathrm{F}$ & $\%$ \\
\hline PNS & 45 & 17,8 \\
\hline Wiraswasta & 49 & 19,4 \\
\hline Buruh & 9 & 3,6 \\
\hline Karyawan Swasta & 62 & 2,5 \\
\hline Ibu Rumah Tangga & 27 & 10,7 \\
\hline Petani & 46 & 18,2 \\
\hline Nelayan & 15 & 5,9 \\
\hline Total & 253 & 100 \\
\hline
\end{tabular}

Pada tabel distribusi frekuensi responden berdasarkan jenis pekerjaan dari 253 responden didapatkan bahwa sebagian besar responden yang jenis pekerjaannya terbanyak yaitu pekerjaan karyawan swasta sebanyak 62 responden $(24,5 \%)$.

\section{Kualitas Pelayanan}

Tabel 2. Gambaran Distribusi Frekuensi

Hubungan Kualitas Pelayanan terhadap

Kepuasan Pasien BPJS Kesehatan di Puskesmas II Denpasar Selatan

\begin{tabular}{lcc}
\hline Kategori & F & $\%$ \\
\hline Kurang Baiik & 33 & 13,0 \\
Baik & 220 & 87,0 \\
\hline Total & 253 & 100 \\
\hline
\end{tabular}

Pada tabel distribusi frekuensi responden berdasarkan kualitas pelayanan didapatkan sebagian besar responden mendapatkan kualitas pelayanan yang baik terhadap kepuasan pasien BPJS Kesehatan berjumlah 220 orang $(87 \%)$.

\section{Kepuasan Pasien BPJS Kesehatan}

Tabel 3. Gambaran Distribusi Frekuensi

Responden tentang Kepuasan Pasien BPJS Kesehatan di Puskesmas II Denpasar Selatan

\begin{tabular}{lcc}
\hline Kategori & F & $\%$ \\
\hline Tidak Puas & 37 & 14,6 \\
Puas & 216 & 85,4 \\
\hline Total & 253 & 100 \\
\hline
\end{tabular}

Pada tabel distribusi frekuensi kepuasan pasien dimana didapatkan sebagian besar responden pasien BPJS Kesehatan di Puskesmas II Denpasar Selatan yang mengatakan puas sebanyak 216 responden $(85,4 \%)$.

\section{Analisa Bivariat}

Hubungan Kualitas Pelayanan terhadap Kepuasan Pasien BPJS Kesehatan

Tabel 4. Hubungan Kualitas Pelayanan terhadap Kepuasan Pasien BPJS Kesehatan di Puskesmas II Denpasar Selatan

\begin{tabular}{lcccccccc}
\hline $\begin{array}{c}\text { Pengaruh } \\
\text { Kualitas } \\
\text { Pelayanan }\end{array}$ & \multicolumn{4}{c}{ Kepuasan Pasien BPJS } & & OR & P \\
\cline { 2 - 5 } & Puas & $\%$ & $\begin{array}{c}\text { Tidak } \\
\text { Puas }\end{array}$ & $\%$ & Total & $\%$ & & value \\
\hline $\begin{array}{l}\text { Kurang Baik } \\
\text { Baik }\end{array}$ & 22 & 9 & 11 & 4 & 33 & 13 & 3,731 & \\
\multicolumn{1}{c}{ Total } & 216 & 77 & 26 & 10 & 220 & 87 & $\begin{array}{c}(1,624 \\
-\end{array}$ & 0,001 \\
\hline
\end{tabular}


IGAA Sherlyna Prihandhani: Hubungan Kualitas Pelayanan Terhadap Kepuasan Pasien BPJS

Kesehatan di Puskemas II Denpasar Selatan

Dari hasil uji statistik dengan Chi-Square didapatkan $\mathrm{p}$ value $=0,001(\alpha=0,05)$, dengan demikian $\mathrm{p}$ value lebih kecil dari alpha sehingga $\mathrm{H}_{0}$ ditolak. Kesimpulannya bahwa ada hubungan antara kualitas pelayanan terhadap kepuasan pasien BPJS Kesehatan di Puskesmas II Denpasar Selatan. Didapatkan hasil $\mathrm{OR}=3,731$, artinya pasien BPJS Kesehatan berpeluang 3,731 kali untuk meningkatkan kepuasan pasien BPJS Kesehatan dilihat berdasarkan dari kualitas pelayanan.

\section{Pembahasan}

Hasil penelitian menunjukkan bahwa responden dengan mengatakan kualitas pelayanan yang baik sebanyak 220 orang (87\%) yang terbagi menjadi dua, yakni responden yang merasa puas dengan kualitas pelayanan yang baik sebanyak 194 orang $(76,7 \%)$ dan responden yang merasa tidak puas dengan kualitas pelayanan yang baik sebanyak 26 orang $(10,3 \%)$. Didapatkan pula responden dengan mengatakan kualitas pelayanan yang kurang baik sebanyak 33 orang (13\%) yang terbagi menjadi dua, yakni responden yang merasa puas dengan mengatakan kualitas pelayanan yang baik sebanyak 22 orang $(8,7 \%)$ dan responden yang merasa tidak puas dengan mengatakan kualitas pelayanan yang kurang baik sebanyak 11 orang $(4,3 \%)$. Hasil analisis bivariat pada tabel 4 didapatkan hasil $\mathrm{p}$ value $=0,001$ $(\mathrm{p}<0,05)$, ini menunjukkan bahwa ada hubungan yang signifikan antara kualitas pelayanan dengan kepuasan pasien BPJS Kesehatan.

Berkaitan teori Nooria (2008) yang mengatakan pelayanan petugas rumah sakit, kecepatan dalam pelayanan rumah sakit dianggap baik apabila dalam memberikan pelayanan lebih memperhatikan kebutuhan pasien maupun orang lain yang berkunjung di rumah sakit.

Hal ini didukung oleh penelitian Aji (2011) berjudul Analisis Pengaruh Kualitas Pelayanan, Harga dan Fasilitas terhadap Kepuasan Pasien (Studi pada
Pasien Klinik As Syifa di Kabupaten Bekasi) dengan 100 responden, didapat hasil pengujian pengaruh kualitas pelayanan terhadap kepuasan pasien diperoleh nilai $t$ hitung $=3,459$ dengan signifikansi 0,001 . Dengan menggunakan batas signifikansi 0,05 , nilai signifikansi tersebut lebih kecil dari 0,05. Dengan arah koefisien positif, maka hipotesis yang menyatakan bahwa kualitas pelayanan memiliki pengaruh positif yang signifikan terhadap kepuasan pasien.

\section{Kesimpulan}

Sebagian besar responden mendapatkan kualitas pelayanan yang baik terhadap kepuasan pasien BPJS Kesehatan berjumlah 220 orang (87\%).

Hasil analisis bivariat pada tabel 5.10 didapatkan hasil $\mathrm{p}$ value $=0,001(\mathrm{p}<0,05)$, ini menunjukkan bahwa ada hubungan yang signifikan antara kualitas pelayanan dengan kepuasan pasien BPJS Kesehatan.

\section{Daftar Pustaka}

Aji, W.K. (2011). Analisis Pengaruh Kualitas Pelayanan, Harga Dan Fasilitas Terhadap Kepuasan Pasien (Studi Pada Pasien Klinik As Syifa Di Kab. Bekasi), http://repository.usu.ac.id/handle/1234 56789/32181. Diakses pada tanggal 28 September 2016 pukul 15.30

Anisza. (2012). Kepuasan Pasien. eprints.ums.ac.id/21823/3/BAB_II.pdf . Diakses pada tanggal 6 Oktober 2016 pukul 12.00

Diman, A. (2015). Hubungan Mutu Pelayanan BPJS Kesehatan Dengan Kepuasan Pasien Di Instalasi Rawat Inap Kelas II Rumah Sakit Umum Daerah

Sekayu,http://repository.unhas.ac.id/bi tstream/handle/123456789/15349

/Jurnal \%20KTI\%20(Agus\%20Diman\%20Sya putra).pdf?sequence 1. Diakses pada tanggal 6 September 2016 pukul 10.00 
IGAA Sherlyna Prihandhani: Hubungan Kualitas Pelayanan Terhadap Kepuasan Pasien BPJS Kesehatan di Puskemas II Denpasar Selatan

Eryan. (2012). Pengaruh faktor-faktor bentuk pelayanan Terhadap kepuasan publik di rumah sakit Bhayangkara Kediri. http://publikasi.uniska-

kediri.ac.id/data/uniska/revitalisasi/revital isasivol1no3des2012/Revitalisasi-

Vol1no3Des201209.\%20Eryan\%20Pram ono.pdf. Diakses pada tanggal 11 Oktober 2016

Enno, M. (2016). Pengaruh Citra Rumah Sakit Dan Kualitas Pelayanan Terhadap Loyalitas Pelanggan Melalui Kepuasan Pelanggan (Studi Pada Rumah Sakit Amal Sehat Wonogiri), http://eprints.uny.ac.id/32082/1/MargitaE nnoYunida12808141015.pdf.Diakses pada tanggal 27 September 2016 pukul 10.00

Handayani. (2015). Determinan Pemanfaatan Pelayanan Kesehatan Oleh Peserta Jamkesmas di Puskesmas Medan. http://repository.usu.ac.id/ bitstream/1234 56789/43333/5/Chapter\%20I.pdf

Hayaza, Y.T. (2013). Analisis Kepuasan Pasien Terhadap Kualitas Pelayanan Kamar Obat di Puskesmas Surabaya Utara. Jurnal ilmiah Mahasiswa Universitas Surabaya, Vol. 2 No. 2, Februari, pp: 2-4.

Herliani, D. (2015). Faktor-faktor yang Mempengaruhi Kepuasan Pengguna BPJS Terhadap Pelayanan BPJS (Studi Kasus: Peserta Pengguna Bpjs Yang Berkunjung Ke Dokter Keluarga/Apotek Di Kabupaten Sleman)

Ismawan, N. (2008). Analisis Kepuasan dan Hubungannya Dengan Loyalitas Pasien Rawat Inap di Rumah Sakit Dedi Jaya Kabupaten Brebes, Semarang

Kesehatan, BPJS. (2014) Indeks Kepuasan Peserta dan Faskes terhadap BPJS Kesehatan Sukses Lampaui Target, https://www.bpjskesehatan.go.id/bpjs/dm documents/46b07615fad0343451d7860b 65909610.pdf. Di akses pada tanggal 16 Desember 2016
Nooria, W. (2008). Pengaruh Persepsi Kualitas Jasa Pelayanan Terhadap Kepuasan dan Loyalitas Pelanggan di RSU Saras Husada Purworejo. Fakultas Psikologi. Universitas Muhammadiyah Surakarta

Norma, L.S. (2012). Pengaruh Tata Letak Ruang Rumah Sakit Terhadap Kepuasan Pasien di Rumah Sakit Umum Pusat H.Adam Malik Medan Tahun 2004. http://repository.usu.ac.id/handle/123456 $789 / 32181$ diakses pada tanggal 11 Oktober 2016

Notoatmodjo. (2010). Metodologi Penelitian Kesehatan. Jakarta: Rineka Cipta

Nursalam. (2011). Manajemen Keperawatan: Aplikasi Dalam Praktik Keperawatan

Profesional. Edisi Ketiga. Salemba Medika. Jakarta.

Sugiyono. (2010). Statistika untuk Penelitian. Alfabeta. Bandung.

Supardi. 2008. Hubungan Antara Persepsi Mutu Pelayanan Pengobatan Dengan Kepuasan Pasien Di Balai Kesehatan Karyawan Rokok Kudus. Tesis, Program Pasca Sarjana Magister Ilmu Kesehatan Masyarakat Universitas Diponegoro, Semarang

Undang-undang Republik Indonesia Nomor 24. (2011). Badan Pelenyelenggara Jaminan Sosial, Republik Indonesia. Jakarta. 